ARAŞTIRMA

\title{
KIRSAL BÖLGEDE YAŞAYAN KADINLARIN VAJINAL AKINTI DURUMUNDA SAĞLIK ARAMA DAVRANIŞLARI
}

\author{
Filiz OKUMUȘ* ～Nurdan DEMIRCI***
}

Alınıs Tarihi: 08.10.2014

Kabul Tarihi: 06.07.2015

\begin{abstract}
$\ddot{O Z Z E T}$
Amaç:Bu araştırma, kirsal bölgelerde yaşayan kadınların vajinal akıntı durumunda sağlık arama davranışlarını ve sağlık arama davranışlarını engelleyen nedenleri belirlemek amacıyla yapılmıştır.

Yöntem: Araştırma, kırsal bir bölgede bulunan bir sağlık ocağı bölgesinde yapılmıştır. Basit rastgele örnekleme yöntemine göre seçilen 438 kadın araştırmaya katılmuştır. Veriler, araştırmacılar tarafindan literatür taranarak hazırlanan veri toplama formu ile toplanmıştır. Değerlendirmede yüzdelik, ortalama ve ki-kare testleri kullanılmıștır.

Bulgular: Araştırmaya katılan kadınların yaş ortalaması 32.1 18.2 olup çoğunluğu 25-29 yaş grubundadır. Sağlık kuruluşuna başvurma oranı oldukça yüksek olup başvuran kadınların bir kısmı hekimin verdiği tedaviyi ya hiç kullanmamış ya da yarıda bırakmıştır. Kadınların vajinal akıntı durumunda sağlık kuruluşuna başvurmama nedenleri akintının kendiliğinden iyileşeceğini düşünmeleri, ekonomik nedenler, zamansızlık, ulaşım zorlukları, utanma, evdeki sorumluluklar, bilgisizlik ve sağllk çalışanlarının ilgisizliğidir.

Sonuçlar: Yaş, eğitim ve çalışma durumu, gelir seviyesi, sağllk sigortası aile tipi, evlenme yaşl, ilk gebelik ve doğum yaşı, gebelik sayısı ile sağllk hizmeti arama davranışı arasında istatistiksel olarak anlamlı bir fark bulunmamıştır.Düşük/küretaj öyküsü açısından gruplar arasında istatistiksel olarak anlamlı farklllık saptanmıştır.
\end{abstract}

Anahtar kelimeler: Sağllk arama davranışl; vajinal akıntı; kırsal nüfus.

ABSTRACT

Health-Seeking Behavior in The Case of Vaginal Discharge in Women Living in Rural Areas

Objective: This research was conducted to determine the behavior of women living in rural areas in terms of seeking healthcare in the event of vaginal discharge and the reasons that hindered their seeking healthcare.

Methods: The study was carried out in a rural area overseen by a community health center. Using the method of random sampling, 438 women participated in the study. Data were collected by the researchers using a data collection form inspired by a scan of the literature. Percentages, means and chi-square tests were used in the evaluation.

Results: The mean age of the women recruited into the study was $32.1 \pm 8.2$ and the majority was in the 25-29 age group. The percentage of women presenting at the health center was noticeably high but a portion of these women either never made use of or never completed the treatment recommended by the physician. The reasons the women did not apply to the health center in the event of vaginal discharge were their thinking that the discharge would disappear by itself, economic rationales, lack of time, transportation difficulties, feeling embarrassed, household responsibilities, ignorance and the indifference of health professionals.

Conclusions: No significant relationship was found between the women's seeking health care and their ages, educational levels, working status, income levels, health insurance status, family type, age of marriage, age of first pregnancy and first delivery, or the number of pregnancies. There was a significant statistical difference observed between the groups in terms of their histories of miscarriage/abortion.

Keywords:Health care seeking behaviour; vaginal discharge; rural population.

\section{GíRIŞ}

Doğum kanalının alt bölümü olan vajina, menstrual kanın boşaldığı ve koitusun gerçekleştiği bir bölgedir. Vajina, kadın internal ve eksternal genital organları arasında bir pasaj özelliği taşıdığından dolayı cinsel sağlık ve üreme sağlığının belirleyicisi olması bakımından kadın sağlığı açısından özel bir öneme sahiptir. Normalde östrojen düzeyi yeterli olan kadınlarda vajinal akıntılar, tüm üreme çağı boyunca çeşitli şekillerde mevcuttur. Ancak zararlı bir etkenin vajinal dokuda uyardığ 1 reaksiyon sonucu

\footnotetext{
*İstanbul Medipol Üniversitesi Sağlık Bilimleri Yüksekokulu, Ebelik Bölümü Yrd.Doç.Dr, e-posta: fokumus@medipol.edu.tr

** Marmara Üniversitesi Sağlık Bilimleri Fakültesi Hemşirelik Bölümü, Doç.Dr.
} 
akıntının özelliği değişir ve anormal vajinal akıntılar meydana gelir. Vajinal akıntılara en çok neden olan enfeksiyon ajanların; trichomonas vaginalis, candida albicans ve bakteriyal vaginozis olduğu bildirilmiştir (Moore and Dalley 2007; Apan 2010).

Dünyada her y1l ortaya çıkan genital organ enfeksiyonlarının yaklaşık yarısı Asya kitasında bulunan ülkelerde meydana gelmektedir (Li, Han, Lee, Lee and Lee 2010). Türkiye, kadınlar arasında vajinal enfeksiyonların yaygın olarak yaşandığ bir ülkelerden biridir. Yapılan bir çalışmada Türk kadınları arasında vajinal enfeksiyon sıklığı \%71 olarak bulunmuştur (Hacialioğlu, İnand 1 ve Pasinlioğlu2000). Başka bir çalışmada Türk kadınlarında trichomonas vaginalis prevalansını \%15.4 olarak bulunmuş ve bunun diğer ülkelere göre yüksek olduğunu bildirilmiştir (Yazar, Dağc1, Aksoy, Üstün, Akısü, Ak ve Daldal 2002). Genital hijyen, vajinal enfeksiyonlardan korunmanın en basit ve önemli bir yolu gibi görünse de kırsal bölgelerde yaşayan kadınlar, genital hijyene yeterince önem verememektedir. Karatay ve Özvarış (2006), Türkiye'de gecekondu bölgelerinde yaşayan kadınların genital hijyene yeterince önem vermediğine dikkat çekmiştir. Beydağ (2009) ise eğitim ve çalışma durumu ile kadınların genital hijyen davranışları arasında istatistiksel olarak anlamlı bir ilişki olduğunu bildirmiştir.

Sağlık arama davranışı "sağlık problemi olan kişilerin uygun tedavi bulmak amaciyla kendi bireysel sorumluluklarını alarak yaptıkları herhangi bir aktivite" olarak tanımlanır (Ward, Mertens and Thomas, 1997). Anormal vajinal akıntılar, vajinal enfeksiyonların en yaygin belirtisi olmasına rağmen çoğu zaman kadınlar tarafindan ihmal edilebilmektedir. Kadınların anormal akıntı durumunda sağlı kuruluşuna başvurarak erken tanı ve tedavi olanaklarından faydalanması şüphesiz kadın sağlığını koruyucu faaliyetlerden biridir. Ebeler ve kadın sağlığ alanında çalışan hemşireler, sağlam ve hasta bireye ulaşma açısından etkin konumda bulunan sağlık çalışanlarıdır. Özellikle vajinal semptomların daha yaygın görüldüğü kırsal kesimlerde ve sosyo-ekonomik düzeyi düşük kadınların anormal vajinal akıntı durumlarının belirlenmesi, sağlık arama davranışları ve aramama nedenlerinin araştırılması birinci basamak sağlık hizmet faaliyetlerini belirlemek açısından önemlidir. Bu çalışma kırsal bir bölgede yaşayan kadınların anormal vajinal akıntı durumunda sağlık hizmeti arama davranışlarını belirlemek ve sağlık hizmeti aramadaki engelleri ortaya çıkarmak amacıyla yapılmıştır.

\section{GEREÇ VE YÖNTEM}

Araştırmanın Şekli: Araştırma kesitsel, tanımlayıcı araştırma tipindedir.

Araştırmanın Yapıldığı Yer ve Zaman: Araştırma, Aralık 2010- Ocak 2011 tarihleri arasında Doğu Akdeniz Bölgesi sinırları içerisinde yer alan Kahramanmaraş ilinde gerçekleştirilmiştir.

\section{Araştırmanın Evren ve Örneklemi:} Araştırmanın evrenini, Kahramanmaraş ilinde bulunan bir sağl1k ocağı bölgesinde yaşayan kadınlar oluşturmaktadır. Araştırmanın yapıldığ 1 sağlık ocağı bölgesinde kadın nüfusu 5578'dir. Araştırmaya katılma kriterleri; evli olmak, gebe ve lohusa olmamak, cerrahi ya da doğal olarak menapoza girmemiş olmak, hormonal ya da antibiyotik/ steroid tedavisi almıyor olmaktır.

Örneklem hesaplanmasında evrendeki birey sayısı bilinen formülünden yararlanılmıştır. Örneklem büyüklüğü hesaplanırken Hacialioğlu, İnand 1 ve Pasinlioğlu (2000)'nun çalışmasına göre \%71'lik enfeksiyon hız fark1 dikkate alınmıştır. Buna göre örneklem büyüklüğü $\% 5$ önemlilik düzeyinde en az 290 olacak şekilde hesaplanmıştır. Kayıplar olabileceği göz önünde bulunularak rastgele sayılar tablosuna göre seçilen evlerde 700 kadınla görüşülmüştür. Araştırma kriterlerine uygun bulunan 512 kadından 438'inin anormal vajinal akıntı şikayeti olduğu için araştırma kapsamına alınmıştır (Sümbüloğlu ve Sümbüloğlu 2010).

Verilerin Toplanması: Veriler, araştırmacılar tarafindan literatür taranarak hazırlanan form ile toplanmıştır. Form, kadınların sosyo-demografik özellikleri, sağlık durumu özellikleri,doğurganlık özellikleri ve sağlık hizmeti arama davranışlarına yönelik soruların yer aldığı dört bölümden oluşmaktadır. Sağlık kuruluşuna başvurmama nedenleri açı uçlu olarak sorulmuştur. Uygulamadan önce Sağlik Yüksekokulu Ebelik Bölümü son sınıf öğrencilerinden oluşan 20 anketöre araştırmanın amacı açıklanmış ve anket formunda yer alan sorular tek tek tartış1mıştır. Anketörler bilgilendirildikten sonra kadınlarla evlerinde görüşülmüsstür. Katılımcılara normal ve anormal akıntı hakkında açıklama yapıldıktan sonra vajinal akıntı şikayeti olan kadınlara araştırma formları yüz yüze görüşme yöntemiyle uygulanmıştır. Her görüşme ortalama $20 \mathrm{dk}$. sürmüştür. Anket sonrasında muayene ve tedavi için sağlık ocağına davet edilmiştir. Kadınların tamamına genital hijyen eğitimi yapılmıştır. 
İzinlerin Alınması: Araştırmanın yapılabilmesi için Kahramanmaraş Sütçü İmam Üniversitesi Tıp Fakültesi Akademik Araştırma Değerlendirme Komisyonu'ndan etik onay alınmıştır. Araştırmanın yapıldığı sağlık ocağı başhekimliğinden gerekli izinler alındıktan sonra veri toplanmaya başlanmıştır. Katılımcılara araştırmanın amacı hakkında bilgi verilerek yazılı ve sözlü izinleri alınarak veriler elde edilmiştir.

Verilerin Değerlendirilmesi: Verilerin istatistiksel analizleri SPSS 15.0 istatistik paket programı kullanılarak yapılmıştır. Verilerin değerlendirilmesinde yüzdelik, ortalama, ki-kare testi kullanılmış, $\mathrm{p}<0.05$ istatistiksel olarak anlamlı kabul edilmiştir.

\section{BULGULAR VE TARTIŞMA}

Toplam 700 kadın, evinde ziyaret edilmiştir. Bu kadınların 512'si araştırma kriterlerine uygun bulunmuş ve onların 438'i anormal vajinal akıntı şikayeti olduğu için araştırma kapsamına alınmıştır. Araştırma yaptığımız bölgede kadınlar arasında anormal vajinal akıntı şikayeti görülme oranı; \%85.5'tir. Vajinal akıntı, kadın hayatının her döneminde karşılaştığı bir durumdur. Çin'in kırsal bir bölgesinde yapılan bir araştırmada kadınların \%92.3'ü hayat1 boyunda en az bir kez üreme yollarını ilgilendiren bir enfeksiyonla karşılaştıklarını ifade etmişlerdir (Li, Han, Lee, Lee and Lee 2010).

Vajinal akıntılar, fizyolojik olabildiği gibi patolojik bir durumun göstergesi de olabilir. $\mathrm{Bu}$ yüzden anormal akıntı durumunda kadınların sağlık arama davranışlarına sahip olması hastalıkların erken tanı ve tedavisi açısından önemlidir. Bu çalışmada kadınların \%77.2'si vajinal akıntı için sağlı kuruluşuna başvurduğunu ifade etmiştir (Tablo 1). Karatay ve Özvarış (2006) Türkiye'de bir gecekondu bölgesinde yaptığı araştırmada geçmişte vajinal akıntı yaşayan kadınların sadece \%36.9'unun hekime başvurduğunu bildirmiştir. Çin'de yapılan bir araştırmada ise son 6 ay içinde akıntı problemi olan kadınların \%11.9'u sağlık kuruluşuna başvururken \%32'sinin eczaneye başvurduğu belirlenmiștir (Guan, Wu, Li, Lin, RotheramBorus, Detels and Hsieh 2009). Hindistan'ın Batı Bengal bölgesinde kırsal bir alanda yapılan bir çalışmada kadınların $\% 75$ 'i kötü kokulu akıntıdan şikayet ettiği halde sadece \%47'si tıbbi tedavi için başvurmuştur (Samanta, Ghosh and Mukherjee 2011). Bir toplumda sağlık arama davranışının yüksek olması, toplumun o hastalık hakkında farkındalığını ve o bölgede sağlik hizmetlerinin mevcudiyetini gösterir. Araştırma yaptığımız bölge şehir merkezine yakındır ve bölgede kolaylıkla ulaşılabilen bir sağlık ocağı bulunmaktadır. Nitekim vajinal akıntı için sağlık kuruluşuna başvuran kadınların çoğu (\%66) sağlık ocağına başvurmuştur (Tablo 1). Ayrıca araştırmanın yapıldığı tarihte sağlık ocağına bağlı olarak çalışan ebeler, yılda iki kez doğurgan yaştaki kadınlara ev ziyaretinde bulunmaktadır.

Kadınların vajinal akıntı için sağlık kuruluşuna başvurmasının yanında reçete edilen ilaçların uygun şekilde kullanması ve ilaç bittikten sonra kontrole gitmesi de önemlidir. Araştırmamızda anormal akıntı şikayeti ile sağlık kuruluşuna başvuran kadınların tamamı hekim tarafından muayene edilerek reçete yazılmışıtır. Fakat kadınların \%20'si hekimin verdiği tedaviyi uygulamadığı ya da yarıda bıraktığını ifade etmiştir (Tablo 1). Herhangi bir rahatsızlık durumunda hekime başvuran hastaların bir bölümü, verilen ilaçları ya hiç kullanmamakta ya da belirtiler kayboluncaya kadar kullanmakta ve tedaviyi yarıda bırakmaktadır. Bhatti and Fikree (2002) tarafindan Pakistan'ın Karachi bölgesinde yapılan bir araştırmada ise kadınlar vajinal problemler için doktorunun verdiği tabletleri ve kremleri kullandığ 1 halde bir süre sonra problemin tekrar geri döndüğünü ifade etmişlerdir. Vajinal enfeksiyonlara neden olan kötü hijyen alışkanlıkları devam ettiği sürece anormal akıntıların tekrar etmesinin mümkün olduğu düşünülmektedir. $\mathrm{Bu}$ durum kadınların tıbbi tedaviye olan inançlarını sarsarak ilaçları yarıda birakmasına neden olabilir.

Çalışmamızda kadınların \%22.8'i vajinal akıntıları olduğu halde sağl1k kuruluşuna başvurmadıklarını ifade etmişlerdir. Çin'de yapılan bir araştırmada ise kadınların neredeyse yarıs1 (\%49.6) üreme yollarını ilgilendiren enfeksiyonlarda doktora başvurmamışlardır ( $\mathrm{Li}$, Han, Lee, Lee and Lee 2010). Araştırmamızda sağlık kuruluşuna başvurmayan kadın oranının diğer araştırmalara göre düşük olmasının nedeni araştırmanın yapıldığ 1 bölgenin sağlık kuruluşlarına yakın olması ve mahallede bir sağlık ocağının bulunmasından kaynaklandığ düşünülmektedir. 
Tablo 1. Vajinal Akıntısı Olan Kadınların Sağlık Hizmeti Arama Davranışlarının Dağılımı

\begin{tabular}{|c|c|c|}
\hline Sağlık Hizmeti Arama Davranışı & $\mathbf{n}$ & $\%$ \\
\hline \multicolumn{3}{|c|}{ Sağlık kuruluşuna başvurma durumu } \\
\hline Başvuran & 338 & 77.2 \\
\hline Başvurmayan & 100 & 22.8 \\
\hline \multicolumn{3}{|c|}{ Sağlık hizmeti aldığı sağlık kuruluşu (n=338*) } \\
\hline Sağl1k ocağ1 & 223 & 66.0 \\
\hline Devlet hastanesi & 80 & 23.7 \\
\hline Özel hastane & 35 & 10.3 \\
\hline \multicolumn{3}{|c|}{ Reçete edilen tedaviyi kullanma durumu ( $\left.\mathrm{n}=338^{*}\right)$} \\
\hline Kullanan & 270 & 79.9 \\
\hline Kullanmayan & 68 & 20.1 \\
\hline \multicolumn{3}{|c|}{ Sağlık hizmeti aramama nedenleri $\left(\mathrm{n}=100^{* *}\right)$} \\
\hline Kendiliğinden geçeceğini düşünme & 48 & 48.0 \\
\hline Ekonomik nedenler & 11 & 11.0 \\
\hline Zamansızlık & 11 & 11.0 \\
\hline Ulaşım zorlukları & 8 & 8.0 \\
\hline Utanma & 7 & 7.0 \\
\hline Evdeki sorumluluklar & 6 & 6.0 \\
\hline Bilgisizlik & 6 & 6.0 \\
\hline Sağllk çalışanlarının ilgisizliği & 3 & 3.0 \\
\hline
\end{tabular}

*Sağlık hizmeti aramayan kadınlar dahil edilmedi,

Araștırmaya katılan kadınların sağlık kuruluşuna başvurmamalarının en büyük sebebi (\%48); vajinal akıntının kendiliğinden geçeceğini düşünmeleridir (Tablo 1). Karatay ve Özvarış (2006) tarafindan yapılan çalışmada anormal akıntı şikayeti yaşayan kadınların \%42.6'sı hiçbir șey yapmadığını ve kendiliğinden geçtiğini ifade etmiştir. Nijeryalı kadınlarda yapılan bir çalışmaya göre ise; kadınların \%54.5' $\mathrm{i}$ semptomların kendiliğinden geçmesi ve kısa sürmesinden dolayı tedavi aramaya gereksinim duymamaktadır (Rabiu, Adewunmi, Akinlusi and Akinola 2010). Kadınlar üreme organlarını ilgilendiren sorunlarda ya tedavi aramay1 reddetmekte ya da ertelemektedir. Ozan ve Özerkan (2008) yaptıkları çalışmada Jinekoloji Polikliniği' 'ne başvuran kadınların \%35'inin bir yılı aşkın süredir anormal akıntıları olduğu halde tıbbi yardım için başvuruda bulunmadığını tespit etmişlerdir. Başka bir araştırmada CYBE'u olan kadınların \%42'sinin tıbbi yardım aramayı en az bir ay erteleyebilmektedir. (Thu Do, Zierch and Hart 2007). Vajinal akıntılar menstruel siklusun fazlarına bağlı olarak kendiliğinden geçmiş gibi görünse de daha sonra tekrar edebilmektedir. Buna bağlı olarak kadınların, sağlık arama zamanını diğer aylara erteledikleri ya da hiç sağlık arama davranışı göstermedikleri düşünülmektedir.

Kadınların vajinal akıntıda tedavi aramamalarının diğer sebepleri; ekonomik nedenler (\%11), zamansızlık (\%11), ulaşım zorluklar1 (\%8), utanma (\%7), evdeki sorumluluklar (\%6), bilgisizlik (\%6) ve săglık çalışanlarının ilgisizliğidir (\%3) (Tablo 1). Yapılan araştırmalarda da kadınların benzer nedenlerden dolayı sağlık kuruluşuna bașvurmadığ1 belirlenmiștir (Rizvi and Luby 2004; El-Kak, Khawaja, Salem and Zurayk 2009).

Araştırma sonuçlarına göre kadınlar, evdeki sorumlulukları ve zamansızlıktan dolayı vajinal akıntı durumunda sağlı aramayı ihmal edebilmektedir. Benzer şekilde Rizvi and Luby (2004), kadınların günlük işlerini aksatmadığ 1 müddetçe sağlı hizmeti aramadığını, önce kendileri tedavi ettiğini ve başarılı olamazlarsa sağlık kuruluşuna başvurduklarını bildirmiştir. Kırsal Mumbai bölgesinde yapılan kalitatif bir araştırmada, kadınların ev içi sorumluluklarından dolayı vajinal akıntı durumunda tedavi aramayı ihmal ettikleri belirlenmiştir (Kostick, Schensul, Jadhav, Singh, Bavadekar and Saggurti 2010).

Araştırmanın yapıldı̆̆ 1 bölge, şehir merkezine yakın ve mahallede bir sağlık ocağ bulunmasına rağmen araştırmaya katılan kadınlardan; ulaşım zorluğundan dolayı sağlık aramayı ihmal ettiklerini ifade edenler olmuştur. Benzer şekilde Bhatti and Fikree (2002) tarafindan Pakistan'in Karachi bölgesinde yapılan bir araştırmada özellikle ileri yaştaki 
kadınlar, sağlık kuruluşuna gitmek için ulaşımın büyük zorluklar yarattığını ifade etmişlerdir.

Araştırmada; kadınlar, anormal vajinal akıntıdan muzdarip olsalar dahi utanma duygusundan dolayı sağlı kuruluşuna başvurmadığını ifade etmiştir. Kırsal kesimlerde yaşayan kadınlar sahip oldukları kültürün ve bir takım geleneksel tutumların etkisiyle tedavi aramamaktadır. Bundan dolayı sağlı arama davranışı sağlık ve cinsiyetle ilişkili faktörlerden ayrı düşünülemez. (Ward, Mertens and Thomas 1997; Bhatti and Fikree, 2002; Tian, Li, Zhang and Guest 2007; Bourne 2009;). Kirsal bölgelerde yaşayan kadınlar üzerinde yapılan çalışmalarda; kadınların, üro-genital sistemi ilgilendiren sorunlarda damgalanma korkusu, utanma ve mahcubiyet duygularından dolayı tedavi aramadıkları bildirilmiştir (Prasad, Abrahan, Kurz, George, Lalitha, John, Jayapaul et al.2005; Lieber, Li, Wu, Rotheram-Borus and Guan 2006; Perera, Kirthinanda, Wijeratne and Wickramarachchi 2014). Benzer şekilde Nepal Katmandu'da yapılan bir çalışmada kadınların vajinal akıntı problemini kimse ile paylaşmamasının nedeni utanmadır (Rizvi and Luby 2004). Hindistan'da yapılan araştırmalarda kadınların mahcubiyet ve utangaçlık nedeniyle genital organlarını ilgilendiren konularda sağlık kuruluşuna başvurmadıkları gösterilmiştir (Barua and Kurz 2001; Kumar1, Singh and Jain 2008). Çin'de yapılan bir araştırmaya göre; kadınlar, jinekolojik problemlerini erkek doktorlara anlatmaktan utandıkların için doktora gitmemektedir ( $\mathrm{Li}$, Han, Lee, Lee and Lee. 2010). Utanma ve mahcubiyet Türkiye'de kırsal bölgelerde yaşayan kadınların sahip olduğu kültürel bir duygudur. Bu kadınlar sağlıklarını ilgilendiren konularda bunu başkaları ile paylaşmakta çekingenlik yaşayabilmekte ve bundan dolayı sağlık arama davranışı göstermemektedir.

Araştırmada; sağlık çalışanlarının ilgisizliği, kadınların vajinal akıntı durumunda sağlı kuruluşuna başvurmama nedenleri arasında yer almaktadır. Nepal Katmandu'da yapılan çalışmaya göre; kadınlar sağlık profesyonellerinin nazik olmadıklarını ve gizliliğe önem vermediklerinden dolayı vajinal akıntı için sağlık kuruluşuna başvurmamaktadır (Rizvi and Luby 2004). Hindistan'da yapılan bir araştırmada kadınların, üreme organlarını ilgilendiren sorunlarda gizliliğin yeterli olmadığını düşündüklerinden sağlık kuruluşuna başvurmadıkları ifade edilmiştir (Prasad, Abrahan, Kurz, George, Lalitha, John, Jayapaul et al.2005). Başka bir çalışma ise Vietnam'da yapılmıştır. Bu çalışmada katılımcılar, sağlık çalışanlarının negatif tutumlarından dolayı CYBE ve GYE durumunda sağlık kuruluşuna başvurmamaktadır (Lan, Faxelid, Chuc, Mogren and Lundborg 2008). Genital organlara ait sağlık problemleri mahremiyetle ilgilidir. Bu tür sağlik problemlerini kadınlar, sağlık çalışanlarına rahatlıkla açıklayamamalarının yanında sağlık çalışanlarından gördükleri tavır ve davranışlar onların sağlık kuruluşuna başvurma isteğini kırabilmektedir.

Araştırmaya katılan kadınların yaş ortalaması 32.1 \pm 8.2 olup çoğunluğu (\%24.7) 2529 yaş grubundadır. Ayrıca kadınların çoğunluğu (\%56.4) ilkokul mezunu olduğunu belirtmiştir. Türkiye Nüfus ve Sağlık Araştırması (TNSA) 2013 verilerine göre; ülkemizde doğurgan yaştaki kadınların çoğunluğu 25-29 yaş grubunda ve kadınlar arasında ilkokul mezunu olma oranı yüksektir. Araştırma sonuçlarımız Türkiye verileri ile benzer sonuçlar içermektedir. Ülkemizde kadınlar arasında istihdam oranı \%31.1'dir (TNSA 2013). Araştırma grubumuzdaki kadınlarda bu oran $\% 7.5$ olup kadınların çoğunluğu (\%41.6), aile gelirinin asgari ücretin altında olduğunu ifade etmiştir. Çalışan kadın oranının Türkiye oranlarına göre düşük olmasının sebebi; araştırma grubumuzun kırsal bölgede yaşayan ve az gelirli ailelerde yaşayan kadınlardan oluşmasından kaynaklandığı düşünülmektedir. Kadınların sosyodemografik özellikleri ile vajinal akıntı durumunda sağlık hizmeti arama davranışı arasında istatistiksel olarak anlamlı bir ilişki bulunmamıştır ( $p>0.05$ ) (Tablo 2).

Katılımcıların genel sağlı durumu özellikleri incelendiğinde; tüm kadınların beden kitle indeksi ortalamasi $26.83 \pm 4.85$ olup çoğunluğu (\%37.9) hafif şişman grubundadır. Kadınların \%22.6'sının kronik bir hastalığ vardır ve bunların \%33.3'ü kronik hipertansiyon, $\% 25$ 'i diyabet, \%24.2'si guatr hastas1 olduğunu bildirmiştir. Tüm kadınların \%12.3'ü sürekli bir ilaç kullandığını ifade etmiştir. Araştırmaya katılan kadınların \%47.2'si sik sik idrar yolu enfeksiyonu geçirdiğini, \%43.6's1 s1k s1k anormal akıntı şikayeti yaşadığını belirtmiştir (Tablo 3). Literatürde kadınların \%10-35'inin yaşamının belli bir döneminde idrar yolu enfeksiyonu geçirdiği bildirilmiştir (Gönen, Akçam ve Yayli 2004). Ürojinekoloji Polikliniği'ne başvuran kadınların \%25.4'üne idrar yolu enfeksiyonu tanıs1 konulmuştur (Özdemir, Çelebi, Nurullahoğlu ve Ak 2006). 
Malatya'da yapılan bir araştırmada ise kadınların \%27'sinin hayatı boyunca en az bir kez genital enfeksiyon yaşadığı ortaya çıkmıştır (Yağmur 2007). Bizim araştırmamızda idrar yolu enfeksiyonu geçirme ve s1k s1k anormal vajinal akıntı yaşama oranının yüksek olması, araştırma grubumuzun özellikle bu tür sağlık problemi olan kadınlardan seçilmesinden kaynaklandığı düşünülmektedir.

Araştırmaya katılan kadınların \%33.1'i üriner inkontinans şikayeti olduğunu belirtmiştir. Yapılan bir araştırmada kadınların \%37.1'inin üriner inkontinans bulguları olduğu tespit edilmiştir (Kök, Şenel ve Akyüz 2006). Başka bir araştırmada Türk kadınları arasında üriner inkontitans prevalansı $\% 31.9$ olarak bulunmuştur (Kocaöz, Talas ve Atabekoğlu 2012).Araştırma grubumuzdaki kadınlarda üriner inkontinans yaşama durumu literatür ile uyumlu bulunmuştur. Kadınların sağlık durumu özellikleri ile vajinal akıntı durumunda sağlık hizmeti arama davranışı arasında istatistiksel olarak anlamlı bir ilişki saptanmamıştır ( $\mathrm{p}>0.05$, Tablo 3).

Tablo 2. Vajinal Akıntısı Olan Kadınların Tanıtıcı Özelliklerine Göre Sağlık Kuruluşuna Başvurup Başvurmama Durumlarının Karşılaştırılması

\begin{tabular}{|c|c|c|c|c|c|c|c|}
\hline \multirow{2}{*}{$\begin{array}{l}\text { Özellikler } \\
\text { Yaș }\end{array}$} & \multicolumn{2}{|c|}{$\begin{array}{c}\text { Sağlık Kuruluşuna } \\
\text { Başvuran } \\
\text { n=338 }\end{array}$} & \multicolumn{2}{|c|}{$\begin{array}{c}\text { Sağlık Kuruluşuna } \\
\text { Başvurmayan } \\
n=100\end{array}$} & \multicolumn{2}{|c|}{ Toplam } & \multirow[t]{2}{*}{$\begin{array}{c}\text { Test ve } \\
\text { p değeri }\end{array}$} \\
\hline & $\mathbf{n}$ & $\%$ & $\mathbf{n}$ & $\%$ & $\mathbf{n}$ & $\%$ & \\
\hline $18-24$ & 69 & 78.4 & 19 & 21.6 & 88 & 20.1 & \\
\hline $25-29$ & 79 & 73.1 & 29 & 26.9 & 108 & 24.7 & \\
\hline $30-34$ & 56 & 73.7 & 20 & 26.3 & 76 & 17.4 & $\chi^{2}=4.488$ \\
\hline $35-39$ & 53 & 81.5 & 12 & 18.5 & 65 & 14.8 & $\mathrm{p}=0.482$ \\
\hline $40-44$ & 50 & 84.7 & 9 & 15.3 & 59 & 13.5 & \\
\hline 45 ve üzeri & 31 & 73.8 & 11 & 26.2 & 42 & 9.6 & \\
\hline \multicolumn{8}{|l|}{ Eğitim durumu } \\
\hline Okula gitmeyen & 78 & 77.2 & 23 & 22.8 & 101 & 23.1 & \\
\hline İlkokul & 184 & 74.5 & 63 & 25.5 & 247 & 56.4 & $\chi 2=3.707$ \\
\hline Ortaokul ve üzeri & 76 & 84.4 & 14 & 15.6 & 90 & 20.5 & $\mathrm{p}=0.157$ \\
\hline \multicolumn{8}{|l|}{ Çalışma durumu } \\
\hline Evet & 27 & 81.8 & 6 & 18.2 & 33 & 7.5 & $\chi 2=0.438$ \\
\hline Hayır & 311 & 76.8 & 94 & 23.2 & 405 & 92.5 & $\mathrm{p}=0.338$ \\
\hline \multicolumn{8}{|c|}{ Aylık gelir durumu } \\
\hline Düzensiz gelir & 49 & 76.6 & 15 & 23.4 & 64 & 14.6 & \\
\hline Asgari ücret $\downarrow$ & 135 & 74.2 & 47 & 25.8 & 182 & 41.6 & $\chi 2=5.956$ \\
\hline Asgari ücret & 76 & 74.5 & 26 & 25.5 & 102 & 23.3 & $\mathrm{p}=0.114$ \\
\hline Asgari ücret $\uparrow$ & 78 & 86.7 & 12 & 13.3 & 90 & 20.5 & \\
\hline \multicolumn{8}{|l|}{ Sağlık sigortası } \\
\hline Var & 85 & 74.6 & 29 & 25.4 & 324 & 74.0 & $\chi 2=0.595$ \\
\hline Yok & 253 & 78.1 & 71 & 21.9 & 114 & 26.0 & $\mathrm{p}=0.259$ \\
\hline \multicolumn{8}{|l|}{ Aile tipi } \\
\hline Çekirdek aile & 267 & 77.6 & 77 & 22.4 & 344 & 78.5 & $\chi 2=0.182$ \\
\hline Geniş aile & 71 & 75.5 & 23 & 24.5 & 94 & 21.5 & $\mathrm{p}=0.382$ \\
\hline
\end{tabular}


Tablo 3. Vajinal Akıntısı Olan Kadınların Sağlık Durumu Özelliklerine Göre Sağlık Kuruluşuna Başvurup Başvurmama Durumlarının Karşılaştırılması

\begin{tabular}{|c|c|c|c|c|c|c|c|}
\hline \multirow{2}{*}{$\begin{array}{l}\text { Özellikler } \\
\text { BKİ }\end{array}$} & \multicolumn{2}{|c|}{$\begin{array}{c}\text { Sağglık Kuruluşuna } \\
\text { Başvuran } \\
\text { n=338 }\end{array}$} & \multicolumn{2}{|c|}{$\begin{array}{c}\text { Sağlık Kuruluşuna } \\
\text { Başvurmayan } \\
n=100\end{array}$} & \multicolumn{2}{|c|}{ Toplam } & \multirow[t]{2}{*}{$\begin{array}{c}\text { Test ve } p \\
\text { değeri }\end{array}$} \\
\hline & $\mathrm{n}$ & $\%$ & $\mathbf{n}$ & $\%$ & $\mathbf{n}$ & $\%$ & \\
\hline Zayıf & 6 & 60.0 & 4 & 40.0 & 10 & 2.3 & \\
\hline Normal & 116 & 78.9 & 31 & 21.1 & 147 & 33.6 & $\chi 2=1.954$ \\
\hline Hafif şișman & 128 & 77.1 & 38 & 22.9 & 166 & 37.9 & $\mathrm{p}=0.582$ \\
\hline Obez & 88 & 76.5 & 27 & 23.5 & 115 & 26.3 & \\
\hline \multicolumn{8}{|c|}{ Kronik hastalık } \\
\hline Var & 77 & 77.8 & 22 & 22.2 & 99 & 22.6 & $\chi 2=0.027$ \\
\hline Yok & 261 & 77.0 & 78 & 23.0 & 339 & 77.4 & $\mathrm{p}=0.494$ \\
\hline \multicolumn{8}{|c|}{ Üriner inkontinans } \\
\hline Var & 109 & 75.2 & 36 & 24.8 & 145 & 33.1 & $\chi 2=0.490$ \\
\hline Yok & 229 & 78.2 & 64 & 21.8 & 293 & 66.9 & $\mathrm{p}=0.484$ \\
\hline \multicolumn{8}{|c|}{ Sık sık idrar yolu enfeksiyonu } \\
\hline Var & 163 & 78.7 & 44 & 21.3 & 207 & 47.2 & $\chi 2=0.553$ \\
\hline Yok & 175 & 75.8 & 56 & 24.2 & 231 & 52.8 & $\mathrm{p}=0.457$ \\
\hline \multicolumn{8}{|c|}{ Sık sık anormal akıntı } \\
\hline Var & 151 & 79.1 & 40 & 20.9 & 191 & 43.6 & $\chi 2=0.686$ \\
\hline Yok & 187 & 75.7 & 60 & 24.3 & 247 & 56.4 & $\mathrm{p}=0.408$ \\
\hline
\end{tabular}

Araștırmamıza katılan kadınların çoğunluğu (\%66.7) $18-24$ yaş aralığında ilk gebelik deneyimini yaşamış, beşte biri (\%20.8) ise adölesan yaşlarda gebe kalmıştır. Araştırma grubumuzda ortanca ilk gebelik yaş1 19'dur (Tablo 4). TNSA 2013 verilerine göre kadınların çoğunluğunun ilk doğumu 25-29 yaş aralığında olup ortanca ilk gebelik yaş1 22.9'dur. Ülkemizde kadınlar 18 yaşına geldiğinde çocuk doğurma oranı keskin bir şekilde artmakta, 17 ve daha erken yaşlarda çocuk doğurma nadirdir. Ancak kırsal alanlarda yaşayan kadınlarda adölesan yaşta çocuk sahibi olma oranı, kentsel alanlarda yaşayanlara göre daha fazladır. Kırsal alanlarda 15-19 yaș grubunda doğurganlık hızı hızlı bir şekilde artmakta 20-24 yaş arasında en üst seviyeye ulaşmaktadır (TNSA 2013). Araştırma grubumuzun kırsal bölgede yaşayan kadınlardan oluşmasından dolayı ilk doğumlarını erken yaşlarda yapmaya eğilimli oldukları düşünülmektedir. Benzer şekilde Barua and Kurz (2001) bildirdiğine göre; Hindistan'da da kadınların çoğu 15-19 yaşında evlendirilmektedir. Bu kadınların sağlık hizmeti alıp almayacağına genellikle eşleri bazen de kayınvalideleri karar vermektedir. Kadınların eşleri, jinekolojik problemlerden dolayı tıbbi hizmete ihtiyacı olduğu konusunda ikna edilememekte ve bu rahatsızlıkların önemini algılayamamaktadır (Barua and Kurz 2001).
Araştırma grubumuzda gebelik sayısı ortalamas1 $3.55 \pm 2.29$ ve doğum sayıs1 ortalamas1 $2.83 \pm 1.81$ 'dir. Medyan gebelik ve doğum sayısı 3 olarak hesaplanmıştır. TNSA 2013'e göre ülkemizde doğurgan yaştaki kadın başına 2.16 çocuk düşmektedir. Kırsal alanda ise bu oran (2.73), kentsel alandan yüzde 21 daha yüksektir. Araştırma grubumuz gebelik ve doğum sayısı açısından TNSA 2013 verileri ile benzerlik göstermektedir. Kadınların ilk gebelik yaşı, doğum ve gebelik sayıları ile vajinal akıntı durumunda sağlık hizmeti arama davranışı arasında istatistiksel olarak anlamlı bir ilişki bulunmamaktadır ( $>00.05$ ) (Tablo 4).

Araștırma sonucunda kadınların $\% 41$ 'inde düşük/küretaj öyküsü bulunduğu belirlenmiştir. Düşük/küretaj öyküsü ile vajinal akıntı durumunda sağlık hizmeti arama arasında istatistiksel olarak anlamlı ilişki olduğu ve bu ilişikinin düşük/küretaj öyküsü olan kadınlarda vajinal akıntı durumunda sağlık kuruluşuna başvurma oranının yüksek olmasından kaynaklandığı saptanmıştır ( $\mathrm{p}=0.039)$ (Tablo 4). $\mathrm{Bu}$ grupta sağlık arama davranışının yüksek olmasının sebebi olarak; düşük ya da küretaj için sağlik kuruluşuna başvurmak gerektiği için sağlık arama deneyimi olan kadınların başka bir sağlık sorununda sağlık arama davranışı gösterme olasıllğının yükseldiği düşünülmektedir. 
Tablo 4. Vajinal Akıntısı Olan Kadınların Doğurganlık Özelliklerine Göre Sağlık Kuruluşuna Başvurup Başvurmama Durumlarının Karşılaştırılması

\begin{tabular}{|c|c|c|c|c|c|c|c|}
\hline \multirow[t]{2}{*}{ Özellikler } & \multicolumn{2}{|c|}{$\begin{array}{c}\text { Sağlık Kuruluşuna } \\
\text { Başvuran } \\
\text { n=338 }\end{array}$} & $\begin{array}{r}\text { Sağl } \\
\text { B }\end{array}$ & $\begin{array}{l}\text { uluşuna } \\
\text { layan } \\
0\end{array}$ & \multicolumn{2}{|c|}{ Toplam } & \multirow[t]{2}{*}{$\begin{array}{c}\text { Test ve p } \\
\text { değeri }\end{array}$} \\
\hline & \multicolumn{2}{|c|}{ Ort \pm SS } & \multicolumn{2}{|c|}{ Ort \pm SS } & \multicolumn{2}{|c|}{ Ort \pm SS } & \\
\hline İlk gebelik yaşı & \multicolumn{2}{|c|}{$20.09 \pm 3.49$} & \multicolumn{2}{|c|}{$19.34 \pm 3.17$} & \multicolumn{2}{|c|}{$19.9 \pm 3.43(19)$} & $\begin{aligned} F & =0.068 \\
p & =0.059\end{aligned}$ \\
\hline Gebelik sayısı & \multicolumn{2}{|c|}{$3.55 \pm 2.19$} & \multicolumn{2}{|c|}{$4.03 \pm 2.36$} & \multicolumn{2}{|c|}{$3.55 \pm 2.29(3)$} & $\begin{array}{l}F=1.417 \\
p=0.640\end{array}$ \\
\hline Doğum sayısı & \multicolumn{2}{|c|}{$2.91 \pm 1.81$} & \multicolumn{2}{|c|}{$3.01 \pm 1.58$} & \multicolumn{2}{|c|}{$2.83 \pm 1.81(3)$} & $\begin{array}{l}F=0.024 \\
p=0.651\end{array}$ \\
\hline İlk gebelik yaşı & $\mathrm{n}$ & $\%$ & $\mathbf{n}$ & $\%$ & $\mathbf{n}$ & $\%$ & \\
\hline Gebelik yok & 9 & 69.2 & 4 & 30.8 & 13 & 3.0 & \\
\hline 17 yaş ve altı & 63 & 69.2 & 28 & 30.8 & 91 & 20.8 & $\chi 2=4.925$ \\
\hline $18-24$ yaş & 232 & 79.5 & 60 & 20.5 & 292 & 66.7 & $\mathrm{p}=0.177$ \\
\hline 25 yaş ve üzeri & 34 & 81.0 & 8 & 19.0 & 42 & 9.6 & \\
\hline $\begin{array}{l}\text { Gebelik sayısı } \\
0 \\
1-2 \\
3-4 \\
5 \text { ve üzeri } \\
\end{array}$ & $\begin{array}{c}9 \\
125 \\
114 \\
90 \\
\end{array}$ & $\begin{array}{l}69.2 \\
80.1 \\
78.6 \\
72.6 \\
\end{array}$ & $\begin{array}{c}4 \\
31 \\
31 \\
34 \\
\end{array}$ & $\begin{array}{l}30.8 \\
19.9 \\
21.4 \\
27.4 \\
\end{array}$ & $\begin{array}{c}13 \\
156 \\
145 \\
124 \\
\end{array}$ & $\begin{array}{c}3.0 \\
35.6 \\
33.1 \\
28.3 \\
\end{array}$ & $\begin{array}{l}\chi 2=2.895 \\
p=0.408\end{array}$ \\
\hline $\begin{array}{l}\text { Doğum sayısı } \\
0 \\
1-2 \\
3-4 \\
5 \text { ve üzeri } \\
\end{array}$ & $\begin{array}{c}11 \\
160 \\
120 \\
47 \\
\end{array}$ & $\begin{array}{l}68.8 \\
79.6 \\
74.5 \\
78.3 \\
\end{array}$ & $\begin{array}{c}5 \\
41 \\
41 \\
13 \\
\end{array}$ & $\begin{array}{l}31.3 \\
20.4 \\
25.5 \\
21.7 \\
\end{array}$ & $\begin{array}{c}16 \\
201 \\
161 \\
60 \\
\end{array}$ & $\begin{array}{c}3.7 \\
45.9 \\
36.8 \\
13.7 \\
\end{array}$ & $\begin{array}{c}\chi^{2}=2.000 \\
p=0.572\end{array}$ \\
\hline $\begin{array}{l}\text { Düşük/küretaj } \\
\text { öyküsü } \\
\text { Var } \\
\text { Yok }\end{array}$ & $\begin{array}{l}130 \\
208\end{array}$ & $\begin{array}{l}72.2 \\
80.6\end{array}$ & $\begin{array}{l}50 \\
50\end{array}$ & $\begin{array}{l}27.8 \\
19.4\end{array}$ & $\begin{array}{l}180 \\
258\end{array}$ & $\begin{array}{l}41.1 \\
58.9\end{array}$ & $\begin{array}{c}\chi 2=4.244 \\
\mathbf{p}=\mathbf{0 . 0 3 9}\end{array}$ \\
\hline
\end{tabular}

\section{SONUÇ VE ÖNERILER}

$\mathrm{Bu}$ çalışmanın sonuçlarına göre; kırsal bölgede yaşayan doğurgan yaştaki kadınların $\% 85.5$ 'i anormal vajinal akıntıdan muzdariptir. Düşük/ küretaj öyküsü ile vajinal akıntı durumunda sağlık hizmeti arama davranışı arasında istatistiksel olarak anlamlı bir ilişki olduğu saptanmıștır. Daha önceden başka bir sebepten dolayı sağlık kuruluşuna başvuran kadınlar, vajinal akıntı durumunda da sağlık hizmeti aramayı ihmal etmemektedir. Örneklem grubumuzda sağlık kuruluşuna başvurma oranı oldukça yüksek olmasına rağmen kadınların bir kısmı hekimin reçete ettiği tedaviyi ya hiç kullanmamış ya da yarıda bırakmıştır. Kadınların vajinal akıntı durumunda sağlik kuruluşuna başvurmama nedenleri; çoğunlukla akıntının kendiliğinden iyileşeceğini düşüncesidir Bunun yanında kadınlar; ekonomik nedenler, zamansızlık, ulaşım zorlukları, utanma, evdeki sorumluluklar, bilgisizlik ve sağlık çalışanlarının ilgisizliği nedenleri ile de sağlık arama davranıșı göstermemektedir.

Bu sonuçlar doğrultusunda önerilerimiz;

- Daha önce sağlik kuruluşuna başvurmamış kadınlar, erken teşhis ve tedavi olanakları konusunda bilgilendirilmelidir.

- Anormal vajinal akıntı şikayeti bulunan kadınlar, reçete edilen ilaçların kullanımı konusunda bilinçlendirilmelidir.

- Menstruel siklus ve vajinal akıntılar konusu, ortaokul ve lise okul ders müfredatlarına eklenmelidir.

- Ev içi sorumlulukları fazla olan kadınlar, riskli grup olarak tespit edilmeli ve izlem sayıları arttırılmalıdır.

- Türkiye'de kadınların sağlık arama davranışlarına yönelik niteliksel araştırmalar planlanmalıdır. 


\section{Teșekkür}

Veri toplama aşamasında anketleri uygulayarak katkıda bulunan Sütçü İmam Üniversitesi Sağlık Yüksekokulu Ebelik Bölümü 2012 mezunlarına ve desteklerini esirgemeyen Kahramanmaraş Merkez Aslanbey Sağlık Ocağı çalı̧̧anlarına teşekkür ederiz.

\section{KAYNAKLAR}

Apan T. (2010). Çevre Mikrobiyolojisi, Normal Flora ve Örnek Alma Teknikleri. İçinde: Hemşireler için Mikrobiyoloji. Ed: Altındiş M, Nobel Tıp Kitabevleri, İstanbul, p.60-6.

Barua A, Kurz K. Reproductive Health-Seeking by Married Adolescent Girls in Maharashtra, India. Reprod Health Matters 2001; 9(17): 53-62.

Beydă K D. Jinekoloji Polikliniğine Başvuran Kadınların Genital Hijyen Davranışları. Atatürk Üniversitesi Hemşirelik Yüksekokulu Dergisi 2009; 12 (2): 105-10.

Bhatti L I, Fikree F F. Health-Seeking Behavior of Karachi Women With Reproductive Tract Infections. Social Science\&Medicine 2002; 54 (1): 105-17.

Bourne P.A.Socio-demographic Determinants of Health Care-Seeking Behaviour, Self-Reported Illnes and Self-Evaluated Health Status in Jamaica. International Journal of Collaborative Research on Internal Medicine\&Public Health 2009; 1(4): 101-30.

El-Kak F, Khawaja M, Salem M, Zurayk H. CareSeeking Behavior of Women With Reproductive Health Problems From Low-İncome Areas of Beirut. International Journal Gynecology and Obstetrics 2009; 104 (1): 60-3.

Gören İ, Akçam FZ, Yaylı G. Kadınlarda Sık Görülen Üriner Enfeksiyonlara Yaklaşım. STED 2004; 13 (4): 128-30.

Guan J, Wu Z, Li L, Lin C, RotheramBorus M J, Detels R, Hsieh $\mathbf{J}$ et al. Self-Reported Sexually Transmitted Disease Symptoms and TreatmentSeeking Behaviors in China. AIDS Patient Care and STDs Mary Ann Liebert, Inc. 2009; 23(6): 443-8.

Hacıalioğlu N, İnandı T, Pasinlioğlu T. Erzurum Ana-Çocuk Sağlığı ve Aile Planlaması Merkezine Başvuran Kadınlarda Genital Yol Enfeksiyonlarının Siklığı ve Risk Faktörleri. Atatürk Üniversitesi Hemşirelik Yüksekokulu Dergisi 2000;3 (2): 11-8.

Karatay G, Özvarış Ş B. Bir Sağlık Merkezi Bölgesindeki Gecekondularda Yaşayan Kadınların Genital Hijyene İlişkin Uygulamalarının Değerlendirilmesi. C.Ü. Hemşirelik Yüksekokulu Dergisi 2006; 10 (1): 7-14.

Kocaöz S, Talas MS, Atabekoğlu CS. Urinary Incontinence Among Turkish Women: An Outpatient Study of Prevalence, Risk Factors and Quality of Life. Journal of Wound, Ostomy and Continence Nursing 2012; 39 (4): 431-9.

Kostick KM, Schensul SL,Jadhav K, Singh R, Bavadekar A, Saggurti N. Treatment Seeking, Vaginal Discharge and Psychosocial Distress Among Women in Urban Mumbai. Cult Med Psychiatry 2010; 34(3): 529-47.
Kök G, Şenel N, Akyüz A. GATA Jinekoloji Polikliniği'ne Bașvuran 20 Yaș Üstü Kadınların Üriner İnkontinans Açısından Farkındalık Durumlarının Değerlendirilmesi. Gülhane Tıp Dergisi 2006; 48(3): 132- 6 .

Kumari S, Singh AJ, Jain V. Treatment Seeking Behavior for Urinary Incontinence Among North Indian women. Indian Journal Med Sci. 2008; 62(9): 352-6.

Lan PT, Faxelid E, Chuc NT, Mogren I, Lundborg CS. Perceptions and Attitudes in Relation to Reproductive Tract Infections Including Sexually Transmitted Infections in Rural Vietnam: A Qualitative Study. Healthpolicy 2008; 86(2-3): 30817.

Lieber E, Li L, Wu Z, Rotheram-Borus MJ, Guan J. HIV/STD Stigmatization Fears as Health-Seeking Barriers in China. AIDS and Behavior 2006; 10(5): 463-71.

Li C, Han H, Lee J, Lee M, Lee Y. Knowledge, Behaviors and Prevalence of Reproductive Tract Infections: A Descriptive Study on Rural Women in Hunchun, China. Asian Nursing Research 2010; 4(3): 122-9.

Moore KL, Dalley AF. (2007). Clinically Oriented Anatomy. Kliniğe Yönelik Anatomi. Çeviri ed: Şahinoğlu K, 4.bs, Nobel Tip Kitabevleri, İstanbul, p.371-3.

Ozan H, Özerkan K.Vajinal Akıntıya Hastaların Yaklaşımı. Uludağ Üniversitesi Tıp Fakültesi Dergisi 2008; 34 (2): 53-4.

Özdemir S, Çelebi İ, Nurullahoğlu N, Ak HC. Ürojinekoloji Kliniğimize Başvuran Üriner İnkontinans Olgularının Dağıılımı. Genel Tıp Dergisi 2006; 16 (2): 49-52.

Perera J, Kirthinanda DS, Wijeratne S, Wickramarachchi TK. Descriptive Cross Sectional Study on Prevalence, Perceptions, Predisposing Factors and Health Seeking Behaviour of Women With Stress Urinary Incontinence. BMC Womens Health 2014; DOI:10.1186/1472-6874-14-78.

Rabiu K A. Adewunmi A A, Akinlusi F M, Akinola O. Female Reproductive Tract Infections: Understanding and Care Seeking Behaviour Among Women of Reproductive Age in Lagos, Nigeria. BMC Women's Health 2010; 10 (8): 1-7.

Prasad JH, Abrahan S, Kurz KM, George V, Lalitha MK, John R., Jayapaul MN et al. Reproductive Tract Infections Among Young Married Women in Tamil Nadu, India. International Family Planning Perspectives 2005; 31 (2): 73-82. 
Rizvi N, Luby S.Vaginal Discharge: Perceptions and Health Seeking Behavior Among Nepalese Women. Journal Pak Med Assoc. 2004; 54(12): 620-4.

Samanta A, Ghosh S, Mukherjee S. Prevalence and Health- Seeking Behavior of Reproductive Tract Infection/Sexually Transmitted Infections Symptomatics: A Cross-Sectional Study of a Rural Community in The Hooghly Dictrict of West Bengal. Indian Journal of Public Health 2011; 55(1): 38-41.

Sümbüloğlu K, Sümbüloğlu V. Biyoistatistik 14 . Bask1.Ankara:Hatipoğlu Yayınevi; 2010. p. 261-9.

Thu Do HT, Zierch A, Hart G. Health Care-Seeking Behaviours for Sexually Transmitted Infections Among Women Attending The National Institute of Dermatology and Venereology in Vietnam. Sex Transm Infect 2007; 83(5): 406-10.
Tian L, Li J, Zhang K, Guest P.Women's Status, Institutional Barriers and Reproductive Health Care: A Case Study in Yunnan. China. Health Policy 2007; 84(2-3): 284-97.

Ward H, Mertens T E, Thomas C. Health Seeking Behaviour and The Control of Sexually Transmitted Disease. Health Policy and Planning 1997; 12(1): 1928.

Yağmur Y. Malatya ili Firat Sağlık Ocağı Bölgesi'nde Yaşayan 15-49 Yaş Kadınların Genital Hijyen Davranışları. TSK Koruyucu Hekimlik Bülteni 2007; 6 (5): 325- 30 .

Yazar S, Dağcı H, Aksoy Ü, Üstün Ş, Akısü Ç, Ak M, Daldal N. Frequency of Trichomonas Vaginalis Among Women Having Vaginal Discharge in Izmir, İnönü Üniversitesi Tıp Fakültesi Dergisi 2002; 9 (3): 159-61. 